\title{
A Cosmopolitan Outlook on Canadian Citizenship: A Case Study in Montreal
}

\author{
Ghada Sfeir
}

University of Saskatchewan

\begin{abstract}
This qualitative study attempts to explore whether seven adults residing in Montreal who have lived for an extended period in more than three countries have experienced a shift toward a cosmopolitan perception in the formulation of their perspectives about their identity, sense of belonging, and citizenship. The qualitative case study was conducted through one-on-one interviews with seven participants. The data were analyzed, coded, and categorized into nine emerging themes. Conceptions of cosmopolitanism are outlined and insights on cosmopolitan education are highlighted. The results of this study call for future research to develop a proposal for a cosmopolitan curriculum that responds to the daily experiences of people in a globally interconnected world by fostering open-mindedness and intercultural competencies. The study is significant to educators, policy makers, and curriculum designers and international program developers.
\end{abstract}

Keywords: cosmopolitanism; citizenship; intercultural competence; curriculum studies 


\section{A Cosmopolitan Outlook on Canadian Citizenship: A Case Study in Montreal}

The world is rapidly growing diverse and human interactions are intensified internationally, nationally, and locally (Rizvi, 2009). Overseas education and global mobility have changed almost every community from being homogenous into a diverse one. Global mobility has also increased cross-cultural, cross-ethnical, interracial, and interreligious marriages and relationships. People are exhibiting multiple identities and loyalties (Osler \& Starkey, 2003). Consequently, questions arise about how nation-states can address the construction of civic communities that account for both diversity of the citizens and the shared values characteristics of a nation (Banks, 2007). These questions have heightened the complexity of the issues around citizenship and identity.

In Canada, multiculturalism has emerged as a concept that attempts to solve this dilemma. However, it has shown that it has multiple shortcomings as "Canada continues to be a hierarchy based on race, ethnicity, and gender" (Ghosh, 2004, p. 562). For example, visible minorities are underrepresented in the federal government, and First Nations as well as other minorities experience discrimination in terms of employment, education, and income. As Appiah (2006) succinctly states, multiculturalism "designates the disease it purports to cure" (p. xiii).

Therefore, it is necessary to reformulate our understandings of identity and citizenship in Canadian society to account to the experiences and multiple perspectives of people whose lives are by-products of these global changes. For these reasons, the construct of cosmopolitanism has been revived to respond to this growing sense of global responsibility and connectedness. However, the concept of cosmopolitanism has generated a controversial debate among intellectuals about its meanings and about how to foster it in education. Therefore, it is important to note that the focus of this study is on a cosmopolitan approach that attempts "to defend emerging spaces for new cultural and social configurations reflective of the intensifying intermingling of people, ideas, and activities the world over" (Hansen, 2008, p. 294). It also addresses the re-construction of social identities that are an outcome of global connectivity, and explores "the dynamics of intercultural relations" (Rizvi, 2009, p. 254). To understand cosmopolitanism in this context, it is necessary to consider the intercultural experiences of international individuals whose lives are re-shaped by various intercultural encounters such as traveling, living, and working in different countries (Rizvi, 2009).

Thus, the purpose of this qualitative study is to examine whether seven adults residing in Montreal who have lived in three or more countries for an extended period have experienced a change toward cosmopolitan perception in the formulation of their perspectives about their identity, sense of belonging, and citizenship. The study aims at capturing meaning making of their experiences through cultural encounters to gain an understanding of whether there are new emerging themes that can shed light on whether intercultural encounters enhance intercultural competence of the participants with the potential to generate cosmopolitan sensibilities. The emerging themes can inform the learning process that aims to foster cosmopolitan sensibilities in students to help them interact with other cultures harmoniously. Cosmopolitan sensibility "embodies more than mere openness to or tolerance of ideas and practices from elsewhere. Rather it is an educational orientation. It features not merely a willingness but a desire to learn from other traditions" (Hansen, 2008, p. 289). The first part consists of a concise review of the literature to outline the various conceptions of cosmopolitanism and their commonalities and contentions. The second part outlines the methodology followed for this research. The findings 
of this research and a discussion of their theoretical and practical implications and limitations conclude the paper.

\section{Review of the Literature}

The following review of the literature consists of three sections. The first section briefly explains the various conceptions of cosmopolitanism. The second one highlights the commonalities and contentions underlying these conceptions. The third section highlights the characteristics of intercultural competencies.

\section{Conceptions of Cosmopolitanism}

The major approaches to cosmopolitanism considered in this paper include moral cosmopolitanism, rooted cosmopolitanism, and cultural cosmopolitanism. Moral cosmopolitanism commits to the moral and equal treatment and respect of each person such that they are unaffected by hierarchy, ethnicity, religion, race, and so forth. Moral cosmopolitanism also emphasizes the notion that people have basic obligations towards all other human beings, but special obligations towards nation, state, and family (Jones, 2010, pp. 116-117).

Appiah (1996) introduces "rooted cosmopolitanism" or what he also calls cosmopolitan patriotism (p. 22). Rooted cosmopolitanism emphasizes higher affiliations to one's home, local culture, politics, and tradition. These local differences and affiliations are distinctive to human beings as long as they are universally ethical and respect basic human rights.

Cultural cosmopolitanism stresses the importance of local culture and values, and rejects the confines of the framework of one's culture and the categorization of others. Simultaneously, cultural cosmopolitanism celebrates cultural borrowing and negates the notion of cultural homogeneity. There are two strands in the literature regarding cultural cosmopolitanism. One strand advocates cultural borrowing, which is today facilitated by global mobility, the media, the Internet, and technology. Cultural borrowing engenders hybridity. Another strand claims that this hybridity is not true: There is a difference between adding something from another culture and being transformed in perspectives, commitments, beliefs, and values as a result of experiencing different cultural forms (Hansen, 2010a).

\section{Commonalities and Contentions about Cosmopolitanism}

A discourse on cosmopolitanism has been currently revived generating an on-going debate among scholars such as Nussbaum (1996), Appiah (1996; 2006), Hansen (2008; 2010a; 2010b), and Jones (2010), among others. The following sketches these various perspectives and their commonalities and contentions about cosmopolitanism mainly in relation to global culture, identity, and citizenship. The conceptual framework adopted in this research is the result of a literature synthesis.

In general, the common feature shared by these scholars is that the world is one single community of human beings. Thus, a cosmopolitan is a citizen of the world who is free from prejudices and biases to a particular cultural, political, or religious group. A cosmopolitan also refers to a person who is open-minded and can live anywhere in the world as if he is at home. The cosmopolitan is impartial and builds a network of international contacts (Kleingeld \& Brown, 2006, p. 7). 
Nussbaum (1996) defines the cosmopolitan as "a person whose allegiance is to the worldwide community of human beings" (p. 4). In other words, it is an allegiance that, at all times, transcends the barriers of patriotic thinking and social differentiation to reach all human beings. Nussbaum (1996) contends that "patriotic pride is both morally dangerous and, ultimately subversive" of justice and equality (p. 4). She states that the patriotic rhetoric that advocates the teaching of basic human rights as a commitment to other nations is limited. It is not enough to teach students that people in other countries have the same human rights without teaching them, for example, about pollution in these countries and their global implications. Referring to the ancient Stoics, the author highlights three main outcomes for an education fostering world citizenship. First, such an education enhances self-knowledge because people understand themselves clearly through their relations with others. This self-knowledge helps them make better assumptions regarding their own practices. Second, international problems such as pollution are better solved with world justice in mind and partisan loyalties are avoided when people are educated to respect other nations' traditions and ways of life. Third, education for world citizenship acknowledges the fundamental goodness in people such as justice and reason (p. 8).

Nussbaum (1996) asserts that being a cosmopolitan does not mean a denial of local affairs or a denial of identification with one's religion, gender, or ethnicity; rather, a cosmopolitan also has affiliations and obligations to humanity at large by being attentive to common values and moral claims and aspirations. Nussbaum (1996) refers to the Stoics' use of the metaphor of the concentric circles where the center consists of the self and the largest circle consists of the humanity to explain what it means to be a citizen of the world (p. 9). Therefore, she emphasizes that education should teach students that their identity is constituted partly of their families, local and religious communities and other affiliations, and partly of humanity as a whole with all that it encompasses as moral values and aspirations.

Hansen (2010b) coined the expression "cosmopolitanism from the ground up" (p. 3) to refer to a cosmopolitanism that is free from dogmatism, elitism, ideological assumptions, heroism, or commitments to particular parties. This cosmopolitanism calls for tolerance of differences as well as willingness to learn from others' perspectives. It is immersed in the daily lives of people, their concerns, commitments, and activities: "What characterises cosmopolitanism from the ground up is a fusion, sometimes tenuous and tension-laden, of the receptivity to the new and loyalty to the known" (Hansen, 2010b, p. 3). Being cosmopolitan is not a permanent identity, but rather it is an expression of loyalty to the known, to one's prior views, and openness to others' perspectives. In particular, daily situations and interactions at particular times inform the cosmopolitan.

Hansen (2010b) also argues that cosmopolitanism refers to the art of living and facing challenges and problems caused by the forces of globalization; yet it is not a solution to these problems. Based on his notion of cosmopolitanism from the ground up, the author endorses a cosmopolitan education that accounts for two dimensions: multicultural and liberal education. Cosmopolitan education acknowledges both an attachment to traditions as well as a critical detachment from them. It engages students with their community's values and traditions while fostering open-mindedness to alternative perspectives to political, religious, and cultural issues.

Osler and Starkey (2003) call for an education for cosmopolitan citizenship that acknowledges the experience of learners in the community, which is also a part of an 
interdependent world. Learners are living in cosmopolitan communities that are highly diverse in terms of race, ethnicity, and culture. These learners have adopted multiple identities and loyalties that are not limited to a national identity. A citizenship education that integrates these experiences is a democratic and inclusive education. It equips people from different backgrounds with knowledge and skills to recognize their rights and responsibilities in an interdependent world, acknowledges humanity, and builds a sense of solidarity with each other so that they can live harmoniously together. A citizenship education that ignores learners' experiences stigmatizes and marginalizes minority groups as they are expected to integrate under the banner of national identity. However, other scholars have expressed their scepticism of cosmopolitanism as a moral and cultural approach. The following highlights some of these views.

By contrast, Miller (2002) argues that though we have moral obligations to others around the world, these obligations are not equal, but rather reciprocal and differentiated within particular political communities. Members of communities want political autonomy and protection of their cultural differences against nullification or privatization (p. 84). However, Appiah (1996) argues that cosmopolitanism is not a threat to cultural heterogeneity; the disappearance of particular cultural features is not new in history and it is accompanied with the constant emergence of new, different ones. Culture is immersed in ever-evolving dynamics.

Himmelfarb (1996) raises several objections to the concept of cosmopolitanism, particularly to Nussbaum's (1996) call for allegiance with humanity at large and for endorsing universal values. Himmelfarb (1996) maintains that universal values such as justice, rights, human treatment of others, and reason are not in reality shared by all human beings; rather, they are values imposed by Western nations that "give them existential reality by incorporating them into their governments, laws, and institutions" (p. 75). Cosmopolitanism with its "unwarranted optimism" is a utopian idea that ignores "unsavory practices that are hardly consonant with the vision of a universal "moral community" such as religious fundamentalism (Himmelfarb, 1996, p. 76). The author emphasizes that the individual's particularities such as culture, family, friends, race, history, and religion, among others, are not "accidental" but essential attributes (p. 77). Identity is not chosen or accidental. It is an essential part of the individual. Himmelfarb (1996) writes, "Cosmopolitanism has a nice, high-minded ring to it, but it is an illusion, and like all illusions, perilous" (p. 77). Similarly, McConnell (1996) sees cosmopolitan education as an abstraction that leads to skepticism about one's own affiliation but not to a shared moral community and, therefore, it is destructive.

Despite these seemingly disparate analyses of cosmopolitanism, a common feature is that human beings are not born cosmopolitan. Cosmopolitanism in its moral and cultural sense is a complex process. In some cases, becoming a cosmopolitan is either the result of a relevant education or social and family upbringing. In others, it is the result of an accumulation of life experiences through a process that encompasses the gradual acquisition of key characteristics of intercultural competence such as knowledge of others, skills to interpret and relate, valuing others, world knowledge, foreign language proficiency, and living other cultures. The following section traces these intercultural characteristics.

\section{Intercultural Competence}

Deardorff (2006) conducted a study to determine a consensus among higher education administrators and intercultural scholars on the key characteristics of intercultural competence 
and appropriate ways to measure it. With respect to ways of assessing intercultural competence, Deardorff found both administrators and intercultural scholars agreed that interviews and case studies are the best methods to be used. With respect to the definition of intercultural competence, her findings state that administrators did not reach a consensus on the definition of intercultural competence and that they used various terminologies to refer to cultural competence. These terminologies are global citizenship, global competence, intercultural competence, and cross-cultural competence. Among the nine definitions presented, they rated the following first two definitions as the highest:

1. "Knowledge of others; knowledge of self; skills to interpret and relate; skills to discover and/or to interact; valuing others' values, beliefs, and behaviours; and relativizing one's self' (Byram, as cited in Deardorff, 2006, p. 247).

2. "Five components: World knowledge, foreign language proficiency, cultural empathy, approval of foreign people and cultures, ability to practice one's profession in an international setting" (Lambert, as cited in Deardorff, 2006, p. 247).

Other common elements of the various definitions of intercultural competence among intercultural scholars include awareness of one's culture as well as others', living other cultures, awareness and respect of cultural differences), valuing other cultures, cultural knowledge, openness and curiosity for other cultures, cultural sensitivity, adaptability to intercultural environments, cognitive flexibility, comparative thinking skills, and "understanding of others' world views" (Deardorff, 2006, pp. 247-248).

In conclusion, on one hand, many scholars throw doubts on the aspirations and feasibility of cosmopolitanism. In this view, cosmopolitanism is an abstraction because it ignores differentiated cultural and individual identities. On the other, there is a strong strand in the literature advocating a cosmopolitan education situated in the intercultural experiences, global connectedness, and ethical engagement between people all over the world. Here, cosmopolitanism is a process that is constantly changing as it draws its meaning from the increasingly complex cultural exchanges, and individuals' perspectives of knowing.

\section{Statement of Purpose}

The purpose of this qualitative study is to examine whether seven adults residing in Montreal who have lived in three or more countries for an extended period have experienced a change toward cosmopolitan perception in the formulation of their perspectives about their identity, sense of belonging, and citizenship. Thus, the main research question is:

What are the emerging themes that justify a cosmopolitan orientation of Canadian citizenship?

The sub-questions are:

1. What are the participants' intercultural experiences?

2. What kind of affective attachments across borders do the participants have?

3. Are there significant similarities or differences in the process of identity development and sense of belonging of the participants between their past and present lives in relation to various host countries? 
4. What are the social and educational factors drawn from the participants' narratives that had an impact on their understanding of citizenship?

\section{Significance of the Study}

The significance of the study lies in its theoretical and practical implications on social and educational policy in an attempt to foster awareness of a new understanding of Canadian citizenship in a globalized era. This study is also significant for educators and curriculum developers of citizenship education and those who are interested in international education due to the similarity of discussions around construction of identity, citizenship, and nationalism. The study also fills two gaps in the literature. Hansen (2010b) points out the lack of research that is analysed from a cosmopolitan perspective in education (p. 1). Hansen also mentions that few scholars have explored the implications of cosmopolitanism on education (p. 2). Further, a dearth of research studies approach the topic of cosmopolitan citizenship from the perspectives of participants.

\section{Methodology}

This section presents the method, descriptions of the participants, procedures utilized, and data collection and analysis.

\section{Research Design}

Considering that this research focuses on a central phenomenon identified as cosmopolitan perceptions and seeks to understand the external factors that are shaping this phenomenon, a qualitative research method was selected. The instrumental case study design was used to explore the activities of the participants within specific contexts to acquire data that address the research questions of this study and "gain a general understanding of the issue" (Stake, 1995, p. 3). The specific contexts for this study are the personal, educational, social, and political lives of the participants in different countries for an extended period. The issues intertwined with these contexts are the general conceptions of relationships between cosmopolitanism and Canadian citizenship.

\section{Participants}

The seven participants are adults residing in Montreal who have lived in at least three countries for an extended period. Four of the participants are females. The participants have been assigned pseudonyms to protect their anonymity. Concept sampling was used to select the participants to help the researcher generate a theory or discover a concept (Creswell, 2011, p. 208). Snowball sampling was also used. Regarding concept sampling, four participants volunteered to participate in the study upon hearing about the topic because they fit the criteria for participants that the researcher was looking for, such as adults who lived in at least three countries for an extended period. Non-Canadian participants, one male and one female, were also included in this study because the topic deals not only with Canadian citizenship but also with cosmopolitanism. I believe that the views of the non-Canadian participants might be useful to identify global commonalities in perspectives and global interconnectivity such as the development of social identity. The following table provides the demographic information of the participants: 
Table 1

Participants' Demographic Information

\begin{tabular}{|c|c|c|c|}
\hline $\begin{array}{l}\text { Interviewees' } \\
\text { Pseudonyms }\end{array}$ & Ethnicity & Language Spoken & $\begin{array}{l}\text { Countries Lived in } \\
\text { for an Extended } \\
\text { Period }\end{array}$ \\
\hline Peter & $\begin{array}{l}\text { Non-Canadian } \\
\text { Both parents are } \\
\text { Peruvian }\end{array}$ & $\begin{array}{l}\text { English Spanish } \\
\text { French } \\
\text { Japanese }\end{array}$ & $\begin{array}{l}\text { England } \\
\text { Japan } \\
\text { France } \\
\text { Canada }\end{array}$ \\
\hline Amal & $\begin{array}{l}\text { Canadian } \\
\text { Both parents of } \\
\text { Indian decent but } \\
\text { born in Guyana }\end{array}$ & $\begin{array}{l}\text { English } \\
\text { French }\end{array}$ & $\begin{array}{l}\text { England } \\
\text { Guyana } \\
\text { Canada }\end{array}$ \\
\hline Tony & $\begin{array}{l}\text { Canadian } \\
\text { His father is from } \\
\text { Syria }\end{array}$ & $\begin{array}{l}\text { English } \\
\text { French } \\
\text { Spanish } \\
\text { German (some) } \\
\text { Italian (some) } \\
\text { Arabic (some) }\end{array}$ & $\begin{array}{l}\text { Canada } \\
\text { Barbados } \\
\text { Syria } \\
\text { Travelled to many } \\
\text { countries }\end{array}$ \\
\hline Vanessa & Mexican Mestiza & $\begin{array}{l}\text { Spanish } \\
\text { English } \\
\text { Italian (some) }\end{array}$ & $\begin{array}{l}\text { Mexico } \\
\text { United States } \\
\text { Canada } \\
\end{array}$ \\
\hline Charlotte & $\begin{array}{l}\text { Canadian } \\
\text { Both parents are } \\
\text { Canadians }\end{array}$ & $\begin{array}{l}\text { French } \\
\text { English } \\
\text { German } \\
\text { (intermediate) } \\
\text { Italian (some) }\end{array}$ & $\begin{array}{l}\text { Belgium } \\
\text { Switzerland } \\
\text { France } \\
\text { Canada }\end{array}$ \\
\hline Dolly & $\begin{array}{l}\text { Canadian } \\
\text { Both parents are from } \\
\text { Europe }\end{array}$ & English & $\begin{array}{l}\text { Canada } \\
\text { Japan } \\
\text { USA } \\
\text { Travelled to Europe, } \\
\text { Mexico and South- } \\
\text { East Asia }\end{array}$ \\
\hline Eli & $\begin{array}{l}\text { Canadian and } \\
\text { Egyptian } \\
\text { His mother is } \\
\text { Lebanese and his } \\
\text { father is from the } \\
\text { Caucasus }\end{array}$ & $\begin{array}{l}\text { English French } \\
\text { Arabic } \\
\text { German (some) } \\
\text { Italian (some) }\end{array}$ & $\begin{array}{l}\text { Egypt } \\
\text { Lebanon } \\
\text { Canada } \\
\text { Travelled to many } \\
\text { countries }\end{array}$ \\
\hline
\end{tabular}




\section{Instrumentation, Data Collection, and Analysis}

Individual face-to-face interviews each of approximately one hour in duration were conducted with each of the participants. One interview was conducted via Skype. The 12 interview questions sought to elicit the participants' activities and experiences in different countries to gain an understanding and formulate meanings of these experiences in specific social, personal, professional, and political contexts (See Appendix A). As Seidman (2006) puts it, data collection through interviews "is a powerful way to gain insight into educational and other important social issues through understanding the experience of the individual whose lives reflect those issues" (Seidman, 2006, p. 14). These meanings were expected to provide answers to the main research questions and to shed light on the focus of the research, which is a cosmopolitan outlook on Canadian citizenship. I also employed what Spradley (1979) called open-ended "grand tour" questions to provide participants freedom in reconstructing and narrating their experiences. The grand tour questions were followed by questions to prompt further illustrations or clarifications.

The first step in the data analysis process was to transcribe each interview and memo the data before the next interview to allow myself a focused reflection on each interview before engaging in interim analysis. Then, the transcripts were examined to identify various codes. These common codes across the participants' responses were compared and directly interpreted in search for common major themes as well as unique themes; several codes, particularly in vivo codes, were immediately identified as they were repeated by several participants such as language, adapt to them, broadminded, culture, foreigner, and difference. These codes were subsequently categorized into nine themes.

\section{Validity: Triangulation, Verification, and Reflexivity}

A researcher cannot enter the interview session theory free (Seidman, 2006). Thus, the interpretive methodology used in analyzing the participants' perspective was influenced by the review of the literature and by my own perspectives and experiences: I have lived in three different countries and experienced a shift in my perceptions about identity, citizenship, education, and openness to an interconnected world. These various experiences, in addition to my previous MA research on transformative learning towards social and emotional competence from a critical perspective are central to my understanding of what engagement with people socially, educationally, and globally might entail. Having said that, I acknowledge, with Porter and Robins (2011), that my "experiences of people, books, social events, and so on, are all conditioned by surrounding circumstances" (p. 2). They might have influenced my interpretations despite my attempt to construct validity.

I was conscious, as Seidman (2006) suggests, of approaching the interview sessions with an intermediate knowledge of the literature on cosmopolitanism and citizenship in order to be able to stay open to the participants' points of view. For synthesizing and interpreting the results, I attempted to strike "a delicate balance between the sometimes competing claims of the relevant literature and the experience of the interview participants" (Seidman, 2006, p. 38). To strike this balance, triangulation was of utmost importance: I verified the procedures for collecting and analyzing the data of this study, ensured construct validity of the interview questions, and used a reflexive approach as an additional source of qualitative rigour throughout the research process. I spaced the interviews to allow myself to transcribe and reflect on the data 
collected. After each interview, I wrote notes to myself about the participants' responses and the thoughts they spurred in me whether these thoughts are biased assumptions, related to the central phenomenon of the research or to subjectivity, keeping in mind that "subjectivity is not seen as failing needing to be eliminated but as an essential element of understanding" in qualitative studies (Stake, 1995, p. 45). Moreover, I coded the data, generated themes and wrote the report of findings with a back and forth reflection on the development of these various parts of the research.

\section{Findings}

The analysis of the seven interviews identified the emergence of several themes that shed light on the research questions. These themes are as follows:

- development of cultural adaptability to confront being foreigners in the host country but no affective attachments across borders,

- local attachment and commitments to one's culture and values,

- cosmopolitan sensibility,

- command of foreign language as a facilitator or barrier for social interconnection,

- awareness of differences,

- disposition to broad-mindedness and impartiality/Cosmopolitan learning,

- development of the characteristics of intercultural competence,

- Montreal as a city with several cosmopolitan features, and

- difficulty in connecting let alone integrating in communities with strong identity.

\section{Theme 1: Development of Cultural Adaptability to Confront Being Foreigners in the Host Country}

All participants found themselves in a situation where they had to confront being foreigners in the host country. Though each had developed different strategies to cope with their situation, they all attempted to adapt to the host country and accepted this adaptation as a necessity for living harmoniously in the host country. Their strategies delineate mainly cultural adaptability to the host country rather than cross-cultural interconnection; however, each participant's approach to "cultural adaptability does not mean uncritically absorbing others" (Hansen, 2008, p. 298), but also finding ways to overcome cultural barriers successfully as Amal explained:

When you move to another country, you have to adapt. You have to say, I have to adapt and what can I do? And I think if you really reach to a point where there is a wall, then it becomes very difficult, but I didn't find any wall that I didn't climb over. (Amal, interview, February 07, 2012)

Eli was born in Egypt. He used to go with his family to Lebanon to spend the summer where he felt labelled:

I used to go to Lebanon for summer holidays... there we were, I would say, illperceived by our relatives from my mother's side. They used to call us Egyptians...We had to adapt to them rather than they to us, and this is something I learnt it early on. You adapt to them and not they to us. Ok. And, I followed this philosophy early on. (Eli, interview, February 16, 2012) 
Similarly, when Tony was talking about one of his cultural encounters in Thailand, he said, "You must learn their approach not your approach" (Tony, interview, March 01, 2012). The participants' views here emphasize the dualism 'us' and 'them' and that obligations and responsibilities in an interdependent world are not reciprocal. They did not have reciprocal expectations in their relationship with the host country. Their way of living in facing challenges and problems depicts to a certain extent more an assimilationist approach rather than a cosmopolitan approach.

\section{Theme 2: Local Attachments and Commitments to One's Culture and Values}

Vanessa, a Mexican student in Montreal, liked Montreal because it is multicultural; she could engage in small talk with everybody, felt safe, had a job and there is more space for her. However, she was trying to build a Mexican community in Montreal because she did not trust people from different cultures.

Tony felt that people in Montreal were attached to their culture:

Montreal, I think, has changed substantially in the sense that they talk a good talk, that everything is wonderful; I still think underneath it all people still go to their little ghettos to a certain extent. They are more comfortable in their own ghettos, but their ghettos now have a much broader interaction with different people, from not only professional differences, but also racial differences, religious differences. (Tony, interview, March 01, 2012)

This theme here intersects with "rooted cosmopolitanism" (Appiah, 2006, p. 22) that emphasizes higher affiliations to one's home and culture. However, it also shows that interactions across differences do not always lead to cosmopolitan sensibility.

\section{Theme 3: Cosmopolitan Sensibility}

The enactment of cosmopolitan sensibility is not shown by adopting different ways of dressing, being familiar with different types of food, and listening to international news. Cosmopolitan sensibility is showing genuine engagement with people by listening to and communicating with them and demonstrating visible respect to their culture, traditions, concerns, ethics, morality, and perspectives (Hansen, 2008, p. 302). Dolly's experience in Japan has nurtured her cosmopolitan sensibility when she engaged with her Japanese friends and enjoyed their way of life. Tony's approach to cultural encounters exemplifies this cosmopolitan sensibility. He said:

I never had superiority to other people. I never tried to impose anything from Canada...If you have enough respect to the people you're working with, that you understand their customs regardless of how important you think you are, how educated you think you are, you realize that when you enter their world, you play by their rules. Most foreigners don't do that...You have to show respect to the community you're in; you can never integrate into a community if you come with your nose in the air. (Tony, interview, March 01, 2012)

It is important to note that Tony developed this cosmopolitan sensibility over many years that included frequent travels. He said that he did not have this sensibility when he was young. Similarly, the other participants did not have this sensibility at a younger age. Moreover, 
Tony showed that he was free from elitism and ideological assumptions, and was willing to learn from others when he said, "I like the fact that my values would be put to the test, and where beneficial, I would accept their values" (Tony, interview, March 01, 2012). Tony's attitude here also exemplifies "cosmopolitanism from the ground up" (Hansen, 2010b, p. 3) which calls for tolerance of differences as well as willingness to learn from others' perspectives.

\section{Theme 4: Command of Foreign Language as a Facilitator or Barrier for Social Interconnection}

All participants repeatedly referred to their command of the foreign language as a vehicle that facilitated or hindered their adaptation to the host country and their engagement in the social and professional interactions or as a barrier for integration. When I asked Tony about the difficulties in adjusting to the host country, he promptly emphasized the importance of learning the host language when he stated, "I never went to a country unless I speak 100 words or more" (Tony, interview, March 01, 2012). Amal stated that her strong command of the English language allowed her to practice her profession in England and Canada. However, Peter and Dolly found it very difficult to integrate in the Japanese society because they did not speak the language. Dolly said: "the language was a huge barrier in Japan and I confronted it by really developing the ability to read body language and to communicate non-verbally" (Tony, interview, March 08, 2012). These experiences suggest that command of the language of the host country is an important intercultural competency that facilitates people's interactions and connections.

\section{Theme 5: Awareness of Differences}

Throughout their journeys in different countries, many participants expressed how they became aware of differences as a normal way of life and not as strangeness. Eli stated, "Each time you confront somebody provoking you, his way, the Lebanese way, you are comparing it to your Egyptian way. You become aware of it" (Eli, interview, February 16, 2012) He also gave an example from India. He explained that if you are walking down the street in India and an Indian wants to know the time, he just grabs your arm, looks at your watch, and then lets it go: "At first you get startled, and then you say it is their way" (Eli, interview, February, 16, 2012).

Dolly recalled an interesting experience that made her conscious of cultural and national differences:

I was really fortunate to travel backpack across Europe before I went to live abroad. And before backpack, I had a bus tour...We did eleven countries in twenty-one days. It is quite intense and my tour guide repeated multiple times a day the sentence "it is not wrong, it is just different." And every time we saw something strange or looked differently, "it is not wrong, it is just different." And that statement that was over 12 years said by my tour, that statement still stays in my mind; every time I was in Japan and I saw something so strange from separate slippers in the bathroom than the rest of the house to the it's ok to pick your nose on the train, but it is not ok to eat on the train; little things like that, I would just repeat my tour guide message, "it is not wrong, it is just different." (Dolly, interview, March 08, 2012) 
However, though these participants developed an awareness of differences, they always felt that being different meant being an outsider as Peter commented on his experience in Japan. The reason is that this awareness is not reciprocated in most cases, or it took quite a significant amount of time before it became reciprocal. Dolly was treated as a foreigner and a minority for about three months before her Japanese friends started to be aware of her and accept her as being different. It was when this awareness of difference became reciprocal, that Dolly had the most enriching social experience in Japan. It is when her managers and her students started to invite her to their homes or take her on trips with them.

\section{Theme 6: Disposition to Broad-Mindedness and Impartiality/Cosmopolitan Learning}

The cultural encounters of participants, whether these encounters were smooth adaptations or cultural clashes, developed in the participants a disposition towards broadmindedness and impartiality. Dolly's experience in Japan left her humbled, and enhanced her cultural sensitivity and increased her awareness of prejudices, which affected her future actions and perceptions of minorities.

In Japan, much more than the US, I was hit with being a minority for the first time of my life...Being a white female from North America living in Japan, I was hit with a lot, I was asked to leave pubs; in conversation, and constantly been, not directly but indirectly, been told that my culture is inferior...I remember having dinner at one of my managers' home and her husband...was talking like the Japanese are superior. And it would be the same way previously; I would be sitting in someone's home in Canada thinking, "Canadians are superior." And, I was never on the flip side of the coin until that moment. (Dolly, interview, March 08, 2012)

Dolly's various encounters in Japan had changed her:

It has changed the way I speak, especially when I was teaching children who are new to Canada; I was always very careful of how I speak about Canada versus any other country, and to keep it on an even plane. (Dolly, interview, March 08, 2012)

She gained what Rizvi (2009) defines as cosmopolitan learning which requires the critical understanding of how our cultural representations and knowledge are socially constituted, and that our cultural encounters allow us to learn about ourselves and transform our perspectives (pp. 266-267). She stated, "I would be a different person if I haven't travelled. I would probably be less confident, less aware of other people's perspectives" (Dolly, interview, March 08, 2012).

Similarly, Tony acquired cosmopolitan learning and he became broadminded and impartial because of his various cultural interactions:

I always said that when we go from here for a certain period to another country, your values come under the microscope; and it is very healthy when you go to other countries...You question your values because I think people who do not travel do not integrate into other cultures, do not question very often their values. I always found that when I would come home, and see the people; I had changed to a certain extent...I liked the fact that my values would be put to the test; and where it was beneficial, I would accept their values. But I did not mean 
that I would reject my values necessarily; I think it made me much, much more broadminded. (Tony, interview, March 01, 2012)

Tony's experience here intersects with the notion of cultural cosmopolitanism that celebrates cultural borrowing and stresses the importance of local culture and values, but rejects being confined within the framework of one's culture (Hansen, 2010a).

\section{Theme 7: Development of the Characteristics of Intercultural Competence}

The development of the characteristics of intercultural competence intersects with the themes described above which are drawn from the participants' experiences. By being exposed to different cultures through their travels, the participants have developed many characteristics of intercultural competence. Significantly, they all became more open-minded as they have repeatedly stated. Both Charlotte and Amal were able to practice their professions in different countries because of their command of the host language. All of the participants exhibited awareness of their own culture as well as others' and demonstrated cultural adaptation. Tony expressed respect for other point of views, beliefs, values, and attitudes. He came to value them as he always "tried to understand the culture" and never tried to impose his own culture on others (Tony, interview, March 01, 2012).

\section{Theme 8: Montreal as a City with Several Cosmopolitan Features}

When the participants were expressing their perspectives about Montreal as a city where they could have their space, they were comparing it to cities or villages with strong identity where they faced either discrimination or where they could not work and socialize. Peter is not Canadian and this is how he felt about Montreal:

So many people from different parts of the world...So I guess that makes it international, the fact that there are a lot of restaurants, you hear a lot of languages. There is the English and French going on. To me that makes it feel international...I really like when people code switch [languages]. I didn't feel out of place. I guess when I arrived, I think I immediately took to it. Yeah. (Peter, interview, February 03, 2012)

Peter liked to live in Montreal because he could teach and work. He spoke English and he did not have to worry about his class. In England, he had to change his accent according to whom he was speaking.

Similarly, Vanessa, a Mexican student in Montreal, did not face racism in Montreal the way she faced it in California: she enjoyed the fact that she could engage in small talk with anyone. She also felt that she could work in Montreal and form her own community. Eli repeatedly emphasized that he lived in three cities not in three countries. For example, he said that he was living in Montreal, not in Quebec, nor in Canada, and he emphasized that he was not a Canadian, nor a Quebecker, but a Montrealer. Then he spoke at length of the opportunities that Montreal offered him culturally, educationally and professionally. To Eli, the borders of citizenship were neither national nor global, but limited to the perimeters of cities. Further, he repeatedly said that he was a guest in this city and that he accepted exclusion that came with French Nationalism. While cosmopolitan learning seeks to expand our understanding of citizenship from the local to the global, it is clear that such learning does not resonate with 
people who share Eli's perspective on Canadian citizenship. Significantly, Eli was not interested in affiliations across borders but in what the local offered him.

\section{Theme 9: Difficulties in Connecting, Let Alone Integrating in Communities with Strong Identity}

Participants who had to live in closed communities with a strong national identity had difficulty integrating or connecting with the local community. They faced discrimination and alienation: Charlotte, a Canadian citizen, was never able to mingle or socialize in Switzerland. She was able to work easily when people around her were from different nationalities but not with the locals (Swiss). Several years ago, but not recently, Tony faced discrimination in Alberta because he was from Quebec. Vanessa faced racism in California because she was Mexican. Both Peter and Dolly, who were Canadians, could not integrate or easily socialize in Japan. They always felt as outsiders. These global experiences are significant because they strongly suggest that cosmopolitan learning and cosmopolitan sensibility can be fostered in communities with international features such as Montreal, but not in communities with a strong identity, whether this identity is national, religious, or political. Thus, when we talk about Canadian citizenship, in general, we are not accounting for the multiple realities of people in all Canadian cities. Further, this theme as well other themes mentioned above add to the complexity of questions regarding citizenship and about how nations-states can address the construction of civic communities that account for both, diversity of the citizens and the shared values characteristics of a nation (Bank, 2007).

\section{Conclusion}

This research provides support that cultural encounters with more than one culture facilitate the development of intercultural competence that has the potential to foster cosmopolitan sensibilities. Accordingly, intercultural competence is not only useful for instrumental purposes such as finding a job in a new country, but also as a tool to bring about positive changes in the perspectives of people confronting a different culture in a host country. These changes include open-mindedness, awareness of difference, respect to 'Others', and positive re-construction of self-identity. Here, intercultural competence is a prerequisite to the development of cosmopolitan sensibilities. However, this identification of the relationship between intercultural competence and cosmopolitan sensibilities is limited due to the small cohort of participants in particular settings. A larger scale research would provide a better understanding of the relationship between intercultural competence and cosmopolitan sensibilities.

The themes generated from the intercultural experiences of the participants in this study are useful for the identification of elements of a cosmopolitan education that promotes openness to new perspectives, respect of difference and self-awareness. These elements include the following: first, it is essential to provide opportunities to encounter difference or 'Otherness' in different settings. The participants did not develop intercultural competence in the classroom, but through lived experiences with strangers in host countries. Second, a strong command of the host country is a significant means for integration and positive interactions. Third, intercultural encounters promote reassessment of one's values and perspectives that could lead to transformation in one's perspectives towards others and in self-awareness. However, the findings do not claim to identify elements that promote equality and moral commitments to humanity. Therefore, there is a need for further research to identify the characteristics of a cosmopolitan 
education that promotes equality and moral commitments in cultural exchanges across differences locally, nationally, and globally. Such an education differentiates between mere cultural adaptability and tolerance on one hand, and genuine and moral engagement, on the other. Cosmopolitan education is a goal worth pursuing to widen our consciousness about our increasingly complex cultural exchanges in a globalized world. 


\section{References}

Appiah, K. A. (1996). Cosmopolitan patriots. In M. C. Nussbaum (Ed.), for love of country? Boston, MA: Beacon Press.

Appiah, K. A. (2006). Cosmopolitanism: Ethics in a world of strangers. New York, NY: W. W. Norten \& Company.

Banks, J. A. (2007). Educating citizens in a multicultural society, (2 ${ }^{\text {nd }}$ ed.). New York, NY: Teachers College Press.

Creswell, J. W. (2011). Educational research: Planning, conducting, and evaluating quantitative and qualitative research, ( $4^{\text {th }}$ ed.). Columbus, OH: Merill Prentice Hall.

Deardorff, D. K. (2006). Identification and assessment of intercultural competence as a student outcome of internationalization. Journal of Studies in International Education, 10, 241263. doi: $10.1177 / 1028315306287002$

Ghosh, R. (2004). Public education and multicultural policy in Canada: The special case of Quebec. International Review of Education, 50, 543-566. Retrieved from http://www.jstor.org/stable/4151617

Jones, C. (2010). Human rights and moral cosmopolitanism. Critical Review of International Social and Political Philosophy, 13(1), 115-135. doi: 10.1080/13698230903326299

Hansen, D. T. (2008). Curriculum, and the idea of a cosmopolitan inheritance. Journal of Curriculum Studies, 40(3), 289-312. doi: 10.1080/00220270802036643

Hansen, D. T. (2010a). Chasing butterflies without a net: Interpreting cosmopolitanism. Stud Philos Educ, 29, 151-166. doi: 10.1007/s11217-009-9166-y

Hansen, D. T. (2010b). Cosmopolitanism and education: A view from the ground. Teachers College Record, 112, 1-21. Retrieved from http://www.tcrecord.org

Himmelfarb, G. (1996). The illusions of cosmopolitanism. In M. C. Nussbaum, For love of country? Boston, MA: Beacon Press.

Kleingeld, P., \& Brown, E. (2006). Cosmopolitanism. Retrieved from http://plato.stanford.edu./entries/cosmopolitanism.

McConnell, M. W. (1996). Don't neglect the little platoons. In M. C. Nussbaum, for love of country? Boston, MA: Beacon Press.

Miller, D. (2002). Cosmopolitanism: A critique. Critical Review of International Social and Political Philosophy, 5(3), 80-85. doi: 10.1080/13698230410001702662

Nussbaum, M. C. (1996). For love of country? Boston, Massachusetts: Beacon Press.

Osler, A., \& Starkey, H. (2003). Learning for cosmopolitan citizenship: Theoretical debates and young people's experience. Educational Review, 55, 243-254. doi:

10.1080/0013191032000118901 
Porter, S. E., \& Robinson, J. C. (2011). Hermeneutics: An introduction to interpretive theory. Cambridge, UK: Wm. B. Eerdmans Publishing.

Rizvi, F. (2009). Towards cosmopolitan learning. Discourse: Studies in the Cultural Politics of Education, 30(3), 293-309. doi: 10.1080/01596300903036863

Seidman, I. (2006). Interviewing as qualitative research, $\left(2^{\text {nd }}\right.$ ed.). New York, NY: Teachers College Press.

Spradley, J. P. (1979). The ethnographic interview. New York, NY: Holt, Rinehart, and Winston.

Stake, R. E. (1995). The art of case study research. Thousand Oaks, CA: Sage Publications 


\section{Appendix A}

\section{Interview Protocol}

Project: Cosmopolitan Outlook on Canadian Citizenship: A Case Study in Montreal

Time of interview:

Date:

Place:

\section{Interviewer:}

\section{Interviewee:}

This qualitative study examines whether adults residing in Montreal who have lived in three or more countries for an extended period have experienced a change in the formulation of their perspectives about their identity, sense of belonging, and citizenship. The study aims at capturing meaning making of their experiences to gain an understanding of whether there are new emerging themes that justify a multicultural or a cosmopolitan orientation of Canadian citizenship.

Data will be stored securely to protect the confidentiality of the responses. Interviewees are given pseudonyms to protect their anonymity.

The interview will take approximately 90 minutes.

Participants need to read and sign the consent form.

Give the participant a $\$ 20$ voucher.

Start recording the interview.

Interview Questions:

1. Where are you from?

2. Tell me a bit about yourself

i. Where are you from?

ii. Tell me about your family/ethnicity

3. In how many countries have you lived so far? For how long?

4. How many languages do you speak?

5. How is it that you came to live in different countries?

6. What difficulties did you face in adjusting to each host country?

7. What did you find easier to deal with in a particular host country as compared to another one?

8. Reflecting back on your experience in each host country, what did you miss the most and what did you miss the least in terms of social, family, educational and professional life?

9. Reflecting on your interaction with people from the host country, what differences in interaction did you perceive, differences that affected you personally?

10. What kind of barriers have you confronted in each country in relation to all aspects of life (occupation, family, friends, and so forth) and what did you do to overcome them?

11. Were you able to fully participate in the social, educational, political, professional arenas in each country?

12. How have your experience in these countries impacted the development of your identity until now?

Note: Thank the interviewees and give assurances of the confidentiality of the responses. 